\title{
"Incidents and Accidents: How Are Schools Implementing the Safety Regulations Prescribed by the South African Schools Act”?
}

\author{
Eric Eberlein $^{1 *}$ and Melanie Moen ${ }^{2}$ \\ ${ }^{* 1}$ Faculty of Education, Education Management and Policy Studies, \\ University of Pretoria, South Africa \\ Telephone: + 2712 4205552, Fax: +27 124205595, E-mail: eric.eberlein@up.ac.za \\ ${ }^{2}$ Faculty of Education, University of Pretoria, South Africa \\ Telephone: + 2712 4205632, Fax: + 12420 5595, E-mail: melanie.moen@up.ac.za
}

KEYWORDS Children’s Rights. Injuries. Liability. Safety Management. School Safety

\begin{abstract}
Children are placed in the care of educators on a daily basis. Accidents and incidents occur despite the best efforts of schools to ensure the safety of children and educators. This study investigated how prepared schools are to keep children and educators safe and also ways of improving school safety. The study was carried out at four urban public schools in South Africa. Interviews, non-participant observations and document analysis were used to investigate the phenomenon. The study indicated, that legislation was not adequately implemented. The main barrier to proper implementation of the Act related to access control and preparedness for searches, child supervision and discipline, preparedness for emergencies, South African Police Services and community relations, school safety policy suitability and implementation, hazards on the schools' premises, understanding the concepts of liability and a lack of Departmental support and staff training. Comprehensive safety training is recommended to improve school safety.
\end{abstract}

\section{INTRODUCTION}

Every day millions of children are placed in the care of educators all across South Africa. A large number of parents place their implicit trust in tens of thousands of schools and educators to keep their children safe and free of injury. Yet, despite the best efforts of educators and principals, incidents of violence and accidents, leading to injuries occur daily. Sometimes these incidents and accidents are of a serious nature and lives are changed forever. When this happens, questions are asked about the causes and what preventative measures can be put in place for the future.

Parents and education role players would like to believe that schools are safe havens, but the reality is shockingly different as the following media reports bear witness - a Grade Eleven pupil in KwaZulu-Natal attempts suicide after allegedly being bullied (Kruger 2013), a Grade Four child is trapped under, and crushed by the

*Address for correspondence:

${ }^{*}$ Eric Eberlein

Faculty of Education,

Education Management and Policy Studies,

University of Pretoria,

South Africa

Telephone: + 27124205552

Fax: + 27124205595 weight of, a movable grandstand on the playground of a primary school in Krugersdorp (Roestoff 2007), six boys between the ages of sixteen and eighteen enrolled at an Afrikaans high school in the northern suburbs of Pretoria are arrested on the school premises for the possession of illegal substances after a surprise police swoop (Fourie 2009), a fifteen year-old girl is stabbed nine times in the chest and back by an ex-pupil-cum-ditched boyfriend as she enters the premises of a high school in Empangeni (Liebenberg 2009), thirty eight children between the ages of five and fifteen years are injured when the unroadworthy school bus in which they were travelling, overturned (Vrey 2014), a thirteen year-old learner at a prestigious public high school for boys in Pretoria suffers serious head injuries when he falls onto his head from a considerable height after a group of older boys flick him into the air with the aid of a cricket net, this learner was subsequently awarded more than ZAR 23.5 million (approximately $\$ 1.56$ million) in damages by the Supreme Court as a result of the injuries he sustained (Verluis 2013).

These and other accidents and incidents of violence do not take place in a legislative vacuum. Legislation such as the South African Schools Act, Act 84 of 1996 (hereafter referred to as the Schools Act) contains detailed and 
specific measures aimed at securing the safety of children at South African schools. Despite the fact, that South Africa has these detailed legislative guidelines, a great number of incidents and accidents are still taking place at schools.

Principals formulate, promulgate, implement and monitor school safety policies at their schools. These policies must be based on the Regulations for Safety Measures at Public Schools (2001) (hereafter referred to as the Regulations) and the Amended Regulations for Safety Measures at Public Schools (2006) (hereafter referred to as the Amended Regulations) as contained in the Schools Act (Act 84 of 1996) and must aim to make practicable these measures and regulations, in order to ensure, the safety and security of the children in their charge. Although, principals are required to implement and regulate these safety measures, there still appears to be a trend of accidents and violence occurring and re-occurring at schools throughout South Africa. Therefore, this paper set out to investigate the extent to which South African schools are implementing the Regulations (2001) and the Amended Regulations (2006) in their efforts to keep the children and educators of the country safe.

\section{What is a Safe School?}

In its most basic form, a safe school is a place where students can learn and teachers can teach in an open and welcoming environment, free of intimidation and violence. (Stevens et al. 2001; Squelch 2001; Oosthuizen 2005; Masitsa 2011). Brendan Barry, an attorney of the High Court of South Africa, says that "....schools owe a legal duty of care to ensure the safety of their learners”. He continues to say that essentially “... this duty requires schools to take reasonable steps to prevent reasonably foreseeable or predictable harm to learners in their care" (Barry 2006: 111). Squelch (2001) states that order is an indispensable condition in any environment where both teaching and learning are expected to take place effectively. Squelch (2001) therefore, defines a safe school as one that is free of danger and possible harm, a place in which everyone may work, teach and learn without fear of ridicule, intimidation, harassment, humiliation or violence. A safe school is a healthy school, when it is physically and psychologically safe.
This is echoed by Mahlangu (2016) who posits, that the term 'school safety' refers to and includes all those critical and necessary environmental factors that allow for the creation of an environment in which effective teaching and learning can take place. He further contends, that a safe school supports learning and at the same time promotes school safety by ensuring that all the stakeholders at the school - children, educators and visitors enjoy a climate that is physically, emotionally, socially and academically secure (Mahlangu 2016). Squelch gives the following indicators of a safe school:

...the presence of certain physical aspects such as a secure wall, fencing and gates, buildings that are in good repair; and well-maintained school grounds...good discipline, a culture of learning and teaching, professional teacher conduct, good governance and management practices and an absence, or low level, of crime and violence" (Squelch 2001: 138).

\section{The Situation at "Ground Zero"}

As early as 2001, Squelch (2001) contended, that many South African schools are unsafe. She further indicated, that the majority of South African schools were in such a poor condition, often with dilapidated buildings and a lack of basic facilities, that they could not be considered safe (2001). She also lamented the lack of good governance and professional management, as factors contributing to the general lack of safety in these schools. Squelch blamed this situation on the failure of the School Governing Bodies (hereafter referred to as SGBs) of many schools to draw up and implement effective school policies, including school safety policies, and ascribes this failure to the fact that the SGBs in many South African schools are not sufficiently equipped to perform this important function (2001). Squelch contended that many South African school buildings and facilities are inadequately maintained by the SGBs as required of them by the Schools Act (Act 84 of 1996), thus contributing to the creation of an unsafe environment. She put this down to the inadequacy of funding for school maintenance and the unavailability of additional funds from within the poor communities that many of these schools serve.

Prinsloo (2005) mentions, very specific issues surrounding child safety at South African 
schools by looking at the Constitution of the Republic of South Africa, Act 108 of 1996. He discusses the right to privacy (s14) in terms of the rights and procedures for conducting searches at schools (Prinsloo 2005), a matter also addressed in both the Regulations (2001) and the Amended regulations (2006). He recommends the re-commitment of each educator in South Africa to professional and ethical conduct and the empowerment by the Department of Education of SGBs, with regard to the drafting and adoption of a code of conduct for children and the maintenance of school buildings and grounds.

Netshitahame and van Vollenhoven see the problem of violence in South African schools as one of the most pressing educational issues and add that, "violence is no longer a stranger in public schools" (2002: 313). Their 2002 study in the Northern Province of South Africa showed that, in most cases, schools in that area had inadequate and/or badly maintained facilities and that most of the principals they interviewed had a very scant understanding of and use for safety policies at their schools. They discovered that in fact, such safety policies existed in only 10 percent of the schools they researched (2002).

Harber (2001) described a training and clustering (schools grouping together for mutual cooperation and benefit) pilot project involving three urban schools to improve their safety situation. The project involved workshops for staff on issues of school safety. It also involved bringing the schools into contact with the South African Police Services to establish service delivery protocols between these parties. Harber (2001) concluded, that schools are not and should not be helpless in the face of violence and crime.

Xaba's (2006) investigation into the safety and security status of schools in the Vaal Triangle region of South Africa found, as did Netshitahame and van Vollenhoven, that most of his target schools had adopted safety policies, but that these policies were not being implemented at all. He also found, that most schools and principals believed that the issue of child safety is a Departmental responsibility. His final conclusion was that "the physical environments of schools need more attention in terms of ensuring that the basic features of safety and security are put in place" (Xaba 2006: 578).
Masitsa's (2011) study of the safety situation in so-called township secondary schools (schools located in the residential areas formerly reserved for black South Africans during the apartheid era) in the Freestate province of South Africa, revealed that not much had changed since the studies of Netshitahame and van Vollenhoven (2002) and Xaba (2006). He found that "despite the Constitution and the plethora of laws protecting teachers and learners in South African schools, scores of them are still unsafe", with "perpetrators of crime and violence in these schools coming from within and without the schools..." (2011: 171).

As alluded to earlier, both the Regulations (2001) and the Amended Regulations (2006) as part of the Schools Act (Act 84 of 1996), address a number of important issues relating to school safety. The 2001 document addresses issues such as public schools, as dangerous weapon and drug free zones (s1), the issue of searches (s4), gaining access to public school premises (s5) of schools' obligation to develop, adopt school safety policies (s9(4) (5)) as well as, the safety-related signages required at South African public schools (s9(1)). The Amended Regulations published in 2006 added to these with issues such as, public schools' obligation to purchase liability insurance (s8(A) 1 to 6 ), the dispensing of medication to children (s8(A)7a), obtaining consent from parents for school trips (s8(C)1), arranging and monitoring the use of transport (s8D), managing dangerous physical activities such as swimming (s8E), fire and emergency procedures (s8F) and managing the early release of children from school (s8G).

It is clear from the literature and from the adoption in 2001 and 2006 respectively, of the Regulations and the Amended Regulations that the issue of school safety in South Africa has enjoyed a great deal of attention in recent years. What can be concluded from the literature is, that many South African schools are unsafe, many schools fail to implement their safety policies, it is difficult to make safety regulations workable and effective, schools seem to rely heavily on their provincial education departments for help and assistance which seldom materialises and that a number of authors (Netshitahame and van Vollenhoven 2002; Xaba 2006) agree, that a greater level of involvement from both the South African Police Service and 
the communities that surround schools would be beneficial to the safety of children at school.

As mentioned before, the researchers investigated the extent to which public schools in South Africa implement the Regulations (2001) and the Amended Regulations (2006) in their efforts to keep all their stakeholders safe. Ways of improving the manner in which schools implement the existing school safety measures and regulations were also discussed.

\section{METHODOLOGY}

\section{Participants}

The study focused on four urban public schools to the east of Pretoria in the Gauteng province of South Africa. Two of these schools were secondary schools while the other two were primary schools. All four schools fall within quintile one or two and are therefore, classified as, so-called 'no-fee' schools (or schools that are not allowed to collect school fees from parents) in terms of section 39 of the Schools Act (Act 84 of 1996).

These schools were selected for their geographic proximity both to one another and to the researchers. Their proximity to one another meant, that they all fell under the same district of the Provincial Department of Education, making it easier to communicate and interact with that Department in the matter of permission to conduct this study. Falling under the jurisdiction of one district also meant, that a greater degree of comparison and generalization was possible during the analysis of the findings. The principals of all the four schools gave their written consent to be part of the study.

The total number of quintile one or two schools in the Gauteng Province is vast, so the researchers employed the principle of convenient sampling and specifically the process of snowball sampling or, as Nieuwenhuis (in Maree 2007) calls it, chain referral sampling, in order to select the four target schools. Nieuwenhuis in the same source defines snowball sampling as, "a method whereby, participants with whom contact has already been made are used to penetrate their social network to refer the researcher to other participants who could potentially take part in or contribute to a study" (Maree 2007: 80).
This study implemented an interpretivist research paradigm to investigate the extent to which public schools implement the Regulations (2001) and Amended regulations (2006). In conclusion, as Nieuwenhuis states, that qualitative data analysis in its essence seeks to "...establish how participants make meaning of a specific phenomenon by analysing their perceptions, attitudes, understanding, knowledge, values, feelings and experiences" (2007: 99), the researchers employed as "fit for purpose" (Cohen et al. 2011: 537) content analysis (Creswell 2014) to analyse the data collected.

\section{Data Gathering}

The data was gathered by employing interviews, non-participant observations and document analysis.

\section{Interviews}

The data was gathered by means of semistructured interviews conducted with the principals of each of the four selected schools. The semi-structured interview, as opposed to the standardized open-ended interview format, was employed as it was a way of increasing the comprehensiveness of the data (Cohen et al. 2011). The weakness of this format, as described by Cohen et al. (2011), is the fact that the ability to generalize from the data can be limited if the interviewer neglects to ensure that each interviewee discusses the same topics and issues. In order to negate this problem, the researchers drew up a schedule of topics and issues. This schedule was provided to each participant in advance of the interview appointment to allow him or her time to prepare.

The interviews were specifically focused on gathering data in such a manner, in which each principal and each school implements the numerous regulations guiding and governing aspects of school safety set out in the Regulations (2001) and the Amended Regulations (2006) as discussed earlier. It was felt that interviews with these four principals, who collectively represented vast and diverse experience of school leadership and management and specifically the management on the issue of school safety, would provide data both enough and of sufficient quantity, to effectively answer the research questions. Using the Regulations (2001) and the Amended 
Regulations (2006) as a framework, the interview questions focused mainly on the principals' understanding of a safe school environment, their knowledge regarding the legislation available to schools, their use and implementation of safety policies, their procedures on reporting incidents and accidents, their greatest needs in ensuring a safe school and the support they receive from the provincial Department of Education to ensure safe schools.

\section{Non-participant Observations}

Non-participant observations were used to gather data first hand (Cohen et al. 2011). In this situation, the researchers acted as Gold's complete observer (Cohen et al. 2011), being completely detached from the situation being observed, not offering any advice or suggestions or prompting any action within the situation under observation. The researchers were there to see what could be seen, rather than to see what was missing or could not be seen.

Each observation was conducted using an observation schedule that included items for observation such as safety signage, the presence and condition of safety and fire-fighting equipment, access control measures and playground duty procedures and habits et-cetera, gleaned from the Regulations (2001) and the Amended Regulations (2006). Time was also spent noting any physical features of each of the schools that might enhance or hamper a school's safety.

\section{Document Analysis}

Every public school in South Africa should as a matter of good management practice and according to section 9(4) and (5) of the Regulations (2001) develop an action plan or school safety policy “...to counter threats of violence which have the potential to have a negative impact on school activities...” This policy or plan "...must ensure the safety of all children, staff members and parents during school activities".

As part of the data gathering for this study, the researchers studied and analysed the school safety policy of each of the four participating schools. This analysis was done with reference to the Regulations (2001) and the Amended Regulations (2006) in order to establish each policy's relevance to each individual school's unique situation, its compliance with the prescripts of the aforementioned regulations and its potential effectiveness as a means of ensuring child, staff and parent safety at school.

\section{RESULTS}

The analysis of all the data gathered brought to light some new and previously unreported patterns and trends concerning the implementation of safety legislation in schools. The main theme of interests and relevance to the issue of school safety identified by this study were access control and preparedness for searches, child supervision and child discipline, levels of preparedness for emergencies, South African Police Services and community relations, school safety policy suitability and implementation, the presence of hazards on the schools' premises, understanding of the concept of liability and Departmental support and staff training.

\section{Access Control and Preparedness for Searches}

Only one school had any form of access control, although all the principals indicated that their school's gates are locked when school commences, the researchers observed this to be so at only two of the four schools in the study.

Similarly, none of the four schools were prepared to conduct searches, with the principals indicating to a man that they themselves lacked knowledge of the procedures for searches - an indicator of lack of knowledge is the fact that one principal indicated that all children at his school together with their possessions were searched by the police on a regular basis without any reasonable suspicion to do so, contrary to the specific stipulations in both the Regulations (2001) and the Amended Regulations (2006).

\section{Child Supervision and Child Discipline}

Lack of proper supervision of the children during class time and on the playgrounds during break was clearly evident during the observation visits. At one school children were left unsupervised during class time for an hour and fifty minutes while educators were busy with a scheduled meeting in the staffroom. Children, in this case two junior primary classes, were also left unsupervised for thirty minutes at one school 
while arrangements were made for a substitute educator. Similarly, the class of an educator at another school was left unsupervised from 08: 00 to $09: 10$ the fact that the educator was late.

At three of the four schools, children as young as Gr. R (5 and 6-year olds) roamed the school premises unsupervised from the time of their arrival at school, some as early as 07: 15, until just before the commencement of the school day. At only one school supervision -children before the commencement of school evident.

Although evidence was found of some form of playground or break duty being performed at all four schools, the regularity of this duty as indicated by a duty roster could not be established at any of the four schools. Generally, those educators observed while performing break duty were adequately placed on the playground, with the exception of one of the schools, where the number of educators on duty also seemed inadequate for the number of children being supervised. At only one school did the researchers observe purposeful interaction between the children and the educators on duty. In a number of other instances the educators failed to address obviously incorrect and/or dangerous behaviour (such as leaving the school premises or playing on dangerous playground equipment) displayed by their charges.

Conversely, all four schools appear to adhere to the regulations for educator-child ratios when arranging and participating in school trips and tours. Finally, it is interesting to note that the school where the worst discipline was observed was also the one where the school safety was the least adequate, while the school where child discipline appeared to be acceptable was the one where safety was the most adequate.

\section{Levels of Preparedness for Emergencies}

At no school could the researchers find more than two fire extinguishers, while none of the extinguishers showed any evidence of having been serviced in the preceding two years. None of the schools were equipped with dedicated and regularly inspected fire hose reels.

Although all four schools were in possession of first aid boxes, at two of the schools these were locked away and not easily accessible. Only at one school did the principal indicate that procedures were in place for the administering of medication to children, although no record of such administration was kept. The remaining three schools do not administer any medication, with one school being fortunate enough to be able to refer sick children to an adjacent clinic. All four schools employed at least one (but in most cases more than one) educator qualified to administer first aid. One school employed, in an unrelated post, a staff member who was also a qualified nurse. From the interviews with the principals it is clear that all four schools have adequate procedures in place to contact the relevant emergency medical response services in the event of a medical emergency. In all but one case (the school adjacent to a clinic) there were no procedures in place to deal with learner health conditions such as epilepsy and diabetes.

Together with the four schools' firefighting equipment, the greatest threat to their ability to deal with emergency situations stemmed from a universal lack of a practicable fire and evacuation plan. Although some principals reported that they had discussed the issue of evacuation with the children at their schools, none of the schools could confirm the regular or even once-off practicing of an evacuation all staff and children from their schools' buildings and grounds.

\section{South African Police Services (SAPS) and Community Relations}

Three of the schools reported good relationships with the local SAPS stations, while the principal at the fourth school felt that his school's relationship, even after a visit to the station commander by himself and the School Governing Body chairperson, remained strained. The schools that claimed good relationships with the police reported that the local stations always respond to requests for assistance and are willing to conduct searches when required.

All four schools reported positive relationships with both the parent community and the surrounding community. All four schools appeared to have launched some form of campaign to advocate their status as drug, alcohol and dangerous object free zones and this enhanced their relationships with the surrounding communities.

\section{School Safety Policy - Suitability and Implementation}

To a partial extent, three of the four schools translated the safety regulations in the Schools 
Act into practicable measures to ensure child safety. However, some of the important issues were neglected. None of the schools adhered to the safety procedures for water-based activities, the administration of medication or the early release of children from school. None of the schools clearly set out the procedures for access control. Indeed, it appears as though the format or basis for these policies originated shortly after the promulgation of the initial Regulations in 2001 and has not been amended or updated since then to incorporate subsequent new school safety regulations.

With regard to the implementation of these policies, all four schools fell short to a certain degree of the effective implementation of even the inadequate policies that exist. If one takes the issue of access control and searches as a gauge, one of the schools, although in possession of a policy that addressed access to the school to some extent, practises no access control at all. One school, in contrast to the trend in the other three schools, practices a far better access control procedure than is prescribed by its school safety policy, but is unprepared for the implementation of procedures for searches contained in its policy. One school's actual access control procedure does not match up to the procedure prescribed in its policy, while the policy of the fourth school contains no prescriptions at all for access control.

\section{The Presence of Hazards on the Schools' Premises}

The premises of all four schools were found to contain, to a greater or lesser degree hazards to the safety of the children enrolled there. The presence of broken glass, building rubble, unguarded water towers, an unsupervised garbage fire, broken and/or unstable and rusted playground equipment, poorly erected barbed wire fences, carelessly strung washing lines, litter (including glass bottles and fluorescent light tubes) all present a real danger to the safety of children.

\section{The Provision of Training, Resources and Support for the Implementation of Safety Legislation}

All but one of the principals felt that Departmental support in the matter of school safety was adequate and that the courses on school safety arranged by the Gauteng Department of Education (GDE) offered to SGB and School
Management Team (SMT) members had been good value. One principal felt, that the Department's involvement was minimal and that the courses offered were not worthwhile attending.

\section{Understanding the Concept of Liability}

From the interviews it was evident that none of the four principals showed a clear understanding of the concept of liability and that none of them could correctly identify the State's liability in terms of section 60(1) of the Schools Act for damages in the event of injuries as a result of an accident or an incident of violence. Section 60 (1) indicates, that the State is liable for any damage or loss caused as a result of any act or omission in connection with any educational activity conducted by a public school and for which such a public school would have been liable but for the provisions of this section.

\section{DISCUSSION}

The safety regulations contained in the Schools Act (Act 84 of 1996), give very clear guidelines for the control of access to public schools (s1 and 4), so the finding that only one school actively controlled access to its premises is alarming. A further cause for concern is the fact that, despite specific mention in both the Regulations (2001) and Amended regulations (2006) of the procedures to conduct searches and to ensure that such schools remain free of illegal drugs, alcohol and dangerous objects, none of the four schools that participated in this study were prepared to conduct such searches, but were content to rely on the timely presence and willingness of the police to fulfil this function. This concern is further compounded by the fact that all four of the participating principals also reported only the most rudimentary knowledge of the procedures for searches.

Almost, complete lack of proper supervision of children during class time and on the playgrounds during break is in direct contravention of s8A (2)(b) of the Schools Act (Act 84 of 1996) which stipulates that children should be supervised at all times. It also flies in the face of what Barry (2006) calls one of the legal duties of the school, that is to keep all the children enrolled in the institution safe by taking steps to ensure proper supervision “...to prevent reasonably foreseeable or predictable harm to learners in their care” (2006: 111). 
As mentioned earlier, it is interesting to note that the school, where the worst discipline was observed was also the one where the school safety was the least adequate, while the school where child discipline appeared to be acceptable was the one where safety was the most adequate. There appeared to be a direct correlation, between the management of child discipline and the general management of the school, including school safety. This finding appears to confirm Squelch's (2001) supposition that order, or in the case of a school - learner discipline - is an indispensable condition for effective teaching and school safety.

The Amended Regulations (2006) section 8F (1) - (4) details fire and other emergency procedures in the eventuality of a fire as follows: "a public school must ensure that it establishes emergency evacuation procedures; the emergency evacuation procedures are displayed in all offices, classrooms and amenities, must take measures to install fire extinguishers, which the principal must ensure are checked regularly; and fire alarms that are audible in all parts of the school premises". In the light of this, the fact that all four schools were found to have vastly inadequate emergency equipment and evacuation procedures is once again cause for grave concern. This lack of preparedness for emergencies indicates a disregard for what Mahlangu (2016) calls the critical and necessary environmental factors that allow for the creation of a safe school environment, while also falling short of a number of Squelch's indicators of a safe school (2001), namely “...the presence of certain physical aspects such as...buildings (and equipment) that are in good repair; and wellmaintained school grounds..." (2001: 138). This finding also appears to confirm Xaba's (2006) conclusion that many schools in South Africa's physical environment (buildings, fences, safety equipment) require additional attention in order to ensure the safety of learners.

In the face of almost overwhelming evidence, that the four participant schools were not implementing the safety regulations in the Schools Act (Act 84 of 1996) well, the finding that all four schools employed at least one educator qualified to administer first aid is heartening. However, although three of the four schools reported no accidents or incidents of violence over the previous two years (one school reported stabbings and fights), it is clear that none of these schools are well enough prepared for the eventuality of a serious emergency, such as a serious injury to a child or the outbreak of a fire.

The good relationship between the schools and the South African Police Service indicates, a level of prudent investment by these schools in their relationship with a role player who would be able to make up to some extent for their own shortcomings with regard to school and learner safety matters. This re-iterates Harbers' (2001) contention that schools through contact with their local South African Police Services station, are not and should not be helpless in the face of violence and crime.

The failure of all four schools to (1) translate the safety measures prescribed in the Regulations (2001) and the Amended Regulations (2006) into practicable school safety policies and (2) effectively implement the policies that they did have, is problematic, and flies in the face of the obligation to develop and adopt school safety policies as stated in s9(4) and (5) of the Amended regulations (2006). This finding also corroborated that of Netshitahame and van Vollenhoven whose 2002 study in the Northern Province of South Africa showed, that most of their participants had a very scant understanding of and use for safety policies at their schools, with only 10 percent of the schools they visited having such policies in place (2002). All policies by their very nature require regular revision and improvement to keep up with the legislation they represent and with the changing situations they are designed to regulate. It is clear from this brief study of the schools' safety policies that this has not been done - most of the content of these policies can be traced back to the original Regulations enacted in 2001. It would therefore be true to say that the school safety policies adopted by these schools are inadequate in their content and also in the manner of their implementation.

The presence of hazards such as, garbage fires and broken glass on the schools' premises can be linked to poorly planned and managed or carelessly executed maintenance. Although, not directly related to the safety regulations contained in the Regulations (2001) and the Amended Regulations (2006), the presence of these hazards threatens each child's right to an environment that is safe and free of harm. This harks back to the recommendation by Prinsloo (2005) that schools require assistance from role players such as provincial Departments of Educa- 
tion in order to remain on top of the maintenance of school buildings and grounds. These findings also confirm Netshitahame and van Vollenhoven's (2002) finding that many schools that were the victims of violence and incidents of injury in the Northern Province of South Africa had inadequate and/or badly maintained facilities.

Although the principals reported, that Departmental support for the issue of ensuring school safety was adequate, the researchers suspect from the lack of specific feedback and the mention of specific training courses by the principals that they underestimate the support required and thus overestimate the support supplied by the provincial department. Although, courses such as first aid and fire fighting were mentioned, the researchers believe that the support offered by the Department lacked the foundation of an extensive and detailed basic school safety course aimed at, among other things, empowering SGBs and school management teams to develop and implement a practicable and effective school safety policy which includes all aspects of the safety regulations prescribed by the Schools Act (Act 84 of 1996).

Finally, the finding, that principals have an inadequate understanding of the concept of liability means that these principals lack a vital component essential for the proper management of the safety situation at schools. Once a school manager understands that the State is liable for damages in the event of an injury sustained as a result of negligence, he or she will better understand the need for liability insurance and also the value of the implementation of an effective and practicable school safety policy as a means of reducing the likelihood of claims against the State and the school while greatly enhancing the safety of children. Finally, none of the four schools carried liability insurance due to the high costs involved.

\section{CONCLUSION}

This study into the implementation of the school safety legislation promulgated by the South African Schools Act (Act 84 of 1996) at four rural public schools east of Pretoria, South Africa has shown that, although in some instances valiant efforts are being made to ensure child safety, most of these schools have, for a variety of reasons, been unable to effectively and adequately implement this legislation, leading to a situation where child safety is compromised. It has also brought to light, the fact that the principals at these schools have but a scant understanding of the State's liability for damages in the event of an injury as a result, an accident or an incident of violence and the effect of this liability on them and their schools. Finally, although nominally present, this study has shown that the level of support for these schools in the matter of school safety from the relevant Department of Education is inadequate to ensure their proper and effective implementation of safety legislation.

\section{RECOMMENDATIONS}

Although all four of the schools that participated in this study have avoided the scourge of violence and the occurrence of serious injuries due to accidents, the findings indicate the definite need for assistance in matters of school safety.

The following recommendations are made to improve school safety:

\section{Comprehensive School Safety Training}

In view of the fact, that all four schools have adopted inadequate school safety policies and have failed to implement these inadequate policies effectively, the researchers recommend the design and implementation of a comprehensive and focused compulsory school safety training course aimed at principals and SGBs. The course should include comprehensive training on aspects such as (1) the content, intent and aims of all the school safety regulations prescribed by the Schools Act (Act 84 of 1996) including aspects such as access control, the procedures for searches, the control and monitoring of public transport contractors and their vehicles, the planning and formalizing of the school's responses to emergencies such as injuries to children and the outbreak of fire, (2) the concept of liability as it relates to public schools in South Africa, including aspects such as vicarious liability, the right to recourse and the need to carry liability insurance, the concept of negligence (specifically as it pertains to schools and educators) and the responsibility of the principal and the SGB towards both the State and the children to ensure the safety of the latter, (3) the method for drafting and adopting a comprehensive, practi- 
cable and effective school-specific safety policy, as well as the management of such policies by the principal and SGB, (4) formalizing and managing the maintenance of the school premises to minimize the number of potential hazards that could threaten the safety of children, (5) the legal requirements to provide adequate supervision of children and strategies to ensure such supervision under various circumstances such as educators arriving late or being absent, children on the playground and children away from the school on trips and tours, (6) practical and practicable strategies for the effective management of child discipline as an important aspect of school safety.

\section{Departmental Support}

Apart from implementing this compulsory school safety training programme, the researchers believe that each provincial Department of Education, through the offices of its various districts, should actively monitor the effective implementation of school safety policies at the schools within their jurisdiction. This should, ideally, involve regular contact with and handson monitoring (including the assessment in terms of school safety of the schools' premises and maintenance regimes) of the safety situation at each school from district or departmental level. This monitoring should also include the creation of an effective and readily available school safety advisory service with the authority and practical knowledge and ability to intervene in the event of a school safety breakdown at any of the schools under its care.

Although, currently available but not widely used, first aid and fire-fighting as well as other emergency training should be compulsory for all staff members (not just educators) employed at public schools.

The appointment of appropriately trained and qualified security personnel is recommended - more and more functions that fall outside the scope of the experience and training of educators are being assigned to them, the conducting of searches and the implementation of effective access control being just two examples of this phenomenon.

It should also be the responsibility of each provincial Department of Education to investi- gate and secure the provision of liability insurance for every school within its jurisdiction.

It is believed that with the implementation of these recommendations, especially those surrounding comprehensive school safety training, the effectiveness with which these schools and others of the same ilk implement the Regulations (2001) and Amended Regulations (2006) contained in the Schools Act (Act 84 of 1996) would improve dramatically.

\section{REFERENCES}

Barry B 2006. Schools and the Law. Cape Town: Juta. Cohen I, Manion L, Morrison K 2002. Research Methods in Education. $5^{\text {th }}$ Edition. London: Routledge Falmer.

Constitution of the Republic of South Africa 1996. The Constitution of the Republic of South Africa, Act 108 of 1996. Cape Town: Government Printer.

Creswell JW 2014. Educational Research: Planning, Conducting and Evaluating Quantitative and Qualitative Research. $4^{\text {th }}$ Edition. Harlow: Pearson.

Harber C 2001. Schooling and violence in South Africa: Creating a safer school. Intercultural Education, 12(3): 261-271.

Hilda Fourie 2009. '6 in arres by Pta-skool oor dwelms'. Beeld March 25, 2009.

Kruger Retha 2013. Deadly Menace of Bullying Continues. Cape Argus, August 1, 2013.

Libenberg Dries 2009. 'Nege keer met mes by skool gesteek'. Beeld April 29, 2009.

Magnus Liela 2006. Nalatigheid van onnies lei tot beserings. Beeld, May 23, 2006.

Mahlangu VP 2016. Legal aspects of sexual harassment. In: K Joubert (Ed.): The Law of Education in South Africa. Pretoria: Van Schaik Publishers, pp. 251-275.

Maree K (Ed.) 2007. First Steps in Research. Pretoria: Van Schaik Publishers.

Masitsa MG 2011. Exploring safety in township secondary schools in the Free State province. South African Journal of Education, 31(1): 163-174.

Netshitahame NE, van Vollenhoven WJ 2002. School safety in rural schools: Are schools as safe as we think they are? South African Journal of Education, 22(4): 313-318.

Nieuwenhuis J 2007. Introducing qualitative research. In: K Maree (Ed.): First Steps in Research. Pretoria: Van Schaik Publishers, pp. 50-55.

Prinsloo IJ 2005. How safe are South African schools? South African Journal of Education, 25(1): 5-10.

Roestoff Amanda 2007. 'Gr.4-leerling sterf in fratsongeluk by skool'. Beeld February 16, 2007.

South African Schools Act 1996. South African Schools Act, Act 84 of 1996. Cape Town: Government Printer. South African Schools Act 1996. South African Schools Act, Act 84 of 1996 Regulations for Safety Measures at Public Schools, Government Gazette no. R1040, 12 October 2001. Cape Town: Government Printers. 
South African Schools Act 1996. South African Schools Act, Act 84 of 1996 Amendment: Regulations for Safety Measures at Public Schools, Government Gazette No. R1128, 10 November 2006. Cape Town: Government Printers.

Squelch J 2001. Do school governing bodies have a duty to create safe schools? An education law perspective. Perspectives in Education, 19(4): 137-150.

Stevens G, Wyngaardt G, Van Niekerk A 2001. The safe schools model: An antidote to school violence? Perspectives in Education, 19(4): 137-149.
Versluis Jeanne-Marie 2013. 'R24 m. vir besering by skool’. Beeld, August 16, 2013.

Very Monique 2014. "38 kinders beseer toe skoolbus omslaan”. Beeld, May 12, 2014.

Xaba M 2006. An investigation into the basic safety and security status of schools' physical environments. South African Journal of Education, 26(4): 565-580.

Paper received for publication on April 2015

Paper accepted for publication on July 2016 